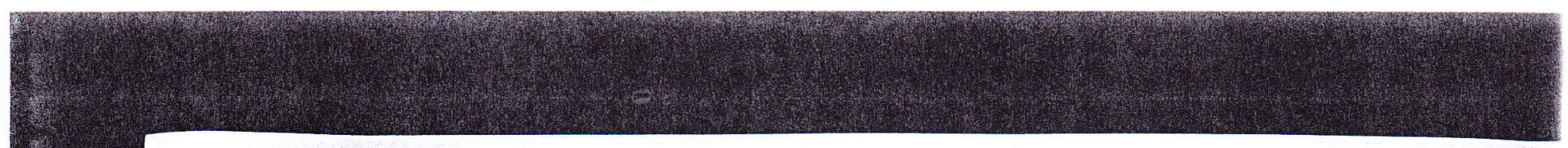

Plant Science 93 (1993) 55-61

\title{
Scoparone eliciting activity released by phosphonic acid treatment of Phytophthora citrophthora mycelia mimics the incompatible response of phosphonic acid-treated Citrus leaves inoculated with this fungus
}

\author{
M.K. Ali ${ }^{a}$, P. Lepoivre*b, J. Semal ${ }^{b}$ \\ aniversity Ain Shams, 11340 Cairo, Egypt \\ ${ }^{h}$ Laboratoire de Pathologie Végétale, Faculté des Sciences Agronomiques, B-5030 Gembloux, Belgium
}

(Received 3 February 1993; revision received 23 April 1993; accepted 16 June 1993)

Abstract

Citrus leaves floating on $\mathrm{H}_{3} \mathrm{PO}_{3}(10 \mu \mathrm{g} / \mathrm{ml})$ were protected from infection by a strain of Phytophthora citrophthora sensitive in vitro to $\mathrm{H}_{3} \mathrm{PO}_{3}$ ( $\mathrm{S}$ strain). Protection was associated with significant scoparone accumulation at the infection site. On the contrary, an $\mathrm{H}_{3} \mathrm{PO}_{3}$ relatively insensitive (RI) mutant of the fungus infected leaves floating on $\mathrm{H}_{3} \mathrm{PO}_{3}$ $(10 \mu \mathrm{g} / \mathrm{ml})$, and did not produce scoparone accumulation. S and RI strains were infectious in leaves floating on control buffer devoid of $\mathrm{H}_{3} \mathrm{PO}_{3}$. Both scoparone accumulation and inhibition of the $\mathrm{S}$ strain in Citrus leaves floating on $\mathrm{H}_{3} \mathrm{PO}_{3}(10 \mu \mathrm{g} / \mathrm{ml})$ were reversed by pretreatment with AOA. In vitro incubation of $P$. citrophthora mycelia in $\mathrm{H}_{3} \mathrm{PO}_{3}$ $(10 \mu \mathrm{g} / \mathrm{ml})$ released a significant scoparone eliciting activity from the S strain, but not from the RI strain, as tested in Citrus leaves. Application of the scoparone eliciting preparation of S strain towards Citrus leaves protected them against infection by either S or RI strain; both scoparone accumulation and leaf protection were suppressed by pretreatment of the leaves with AOA. Thus, scoparone elicitors released in vitro by $\mathrm{H}_{3} \mathrm{PO}_{3}(10 \mu \mathrm{g} / \mathrm{ml})$ treatment of mycelia of the $\mathrm{S}$ strain (but not of the RI strain) of $P$. citrophthora, mimic the incompatible response observed in $\mathrm{H}_{3} \mathrm{PO}_{3}$-treated Citrus leaves inoculated with the $\mathrm{S}$ strain (but not with the RI strain) of the fungus.

Key words: Phosphonic acid; Phytophthora citrophthora; Citrus; Elicitor; Scoparone

\footnotetext{
* Corresponding author.

Abbreviations: AOA, $\alpha$-aminoacetic acid; CEP, crude elicitor preparation; CMA, corn meal agar: EP, eliciting preparations; MES, $N$-morpholino ethane sulfonic acid.
}

\section{Introduction}

Fosetyl-Al (aluminium tris-O-ethylphosphonate, trade name Aliette ${ }^{\circledR}$ ), has little in vitro effect on mycelial growth of most oomycetes, while controlling a number of diseases they cause in plants. 
In treated plants, fosetyl-Al is degraded to phosphonic acid $\left(\mathrm{H}_{3} \mathrm{PO}_{3}\right)$, which appears to be the active component involved in disease control [1].

A number of observations supported the hypothesis that host reactions are involved in the protection of plants by phosphonates [2-4], but it was also suggested that these chemicals might act through a direct toxicity towards plant pathogens $[5,6]$.

We have shown previously that floating leaves on fosetyl-Al or $\mathrm{H}_{3} \mathrm{PO}_{3}$ prevented infection by a fosetyl- $\mathrm{Al}$ and $\mathrm{H}_{3} \mathrm{PO}_{3}$ sensitive $\mathrm{S}$ strain of Phytophthora citrophthora, but not infection by a mutant of the fungus relatively insensitive (RI) to fosetyl$\mathrm{Al}$ and $\mathrm{H}_{3} \mathrm{PO}_{3}$ [7]. We also found that preinoculation of leaves floating on $\mathrm{H}_{3} \mathrm{PO}_{3}$ with the $\mathrm{S}$ strain prevented infection by the subsequently inoculated $\mathrm{R}$ strain. This suggested that a general resistance mechanism was induced by inoculating the S strain (but not the RI strain) of $P$. citrophthora to fosetyl$\mathrm{Al}$ (or $\mathrm{H}_{3} \mathrm{PO}_{3}$ ) treated Citrus leaves.

Resistance of Citrus stems towards P. citrophthora was found to be linked to the accumulation of scoparone, a phytoalexin associated with disease resistance in Citrus [8]. This led us to test whether elicitors of scoparone might be associated with the different behaviour of the $\mathrm{S}$ and $\mathrm{RI}$ strains of $P$. citrophthora, when inoculated to Citrus leaves in the presence of phosphonic acid. Our earlier observations have shown that in vitro incubation of the myceli of $P$. citrophthora in fosetyl-Al released scoparone eliciting activity from the S, but not from the RI strain [9].

In the present paper, we investigated the possible involvement of scoparone elicitors in the incompatible response observed when Citrus leaves, floating on $\mathrm{H}_{3} \mathrm{PO}_{3}$, were inoculated with the $\mathrm{S}$ strain of $P$. citrophthora, while a compatible reaction was obtained upon inoculation of the RI strain by itself.

In order to avoid the problems linked to possible direct effects of $\mathrm{H}_{3} \mathrm{PO}_{3}$ on the leaf or on the inoculum, we choose to use the in vitro release of scoparone elicitors by $P$. citrophthora mycelia as a differential marker of the in planta effects of phosphonic acid on leaf infection by the $\mathrm{S}$ or the RI strain.

\section{Materials and methods}

\subsection{Fungal isolates, plants and inoculation pro- cedure}

Two strains of $P$. citrophthora, either sensitive (S strain; $\mathrm{EC}_{50}=6.5 \mu \mathrm{g} / \mathrm{ml}$ ), or relatively insensitive (RI) mutant $\left(\mathrm{EC}_{50}=125.3 \mu \mathrm{g} / \mathrm{ml}\right)$ [7] to fosetyl-Al and $\mathrm{H}_{3} \mathrm{PO}_{3}$, were maintained on $\mathrm{CMA}$ at $25^{\circ} \mathrm{C}$, and were inoculated onto wounded leaves of rough lemon (Citrus jambhiri) [10].

Surface-sterilized leaves were wounded along the main vein and were placed to float, adaxial side up, on a solution of $10 \mu \mathrm{g} / \mathrm{ml} \mathrm{H}_{3} \mathrm{PO}_{3}$ buffered at pH 6.2 with $0.03 \mathrm{M} \mathrm{MES,} \mathrm{with/without} 300 \mu \mathrm{M}$ AOA. This concentration of phosphonic acid was chosen as in planta, it inhibited lesion size with the $\mathrm{S}$ strain, but not with the RI strain of $P$. citrophthora; such inhibition was entirely reversed by pretreatment with AOA. Inoculation was performed $2 \mathrm{~h}$ after wounding by placing an agar disc $(0.4 \mathrm{~cm}$ in diameter $)$ taken from 5 -day-old colonies of $P$. citrophthora, at the site of the wound. After 5 days of incubation at $25^{\circ} \mathrm{C}$ in the dark, the diameter of lesions was recorded.

\subsection{Release of scoparone elicitors by $P$. citrophthora mycelia}

Mycelia of the S strain (or of the RI strain) of $P$. citrophthora, were incubated in vitro for 6 days in $0.03 \mathrm{M}$ MES buffer, $\mathrm{pH} 6.2$, with/without 10 $\mu \mathrm{g} / \mathrm{ml} \mathrm{H}_{3} \mathrm{PO}_{3}$. The incubation fluids were filtered, treated with ethanol, and the precipitates were resuspended in $0.03 \mathrm{M} \mathrm{MES}(\mathrm{pH}$ 6.2) containing $10 \mu \mathrm{g} / \mathrm{ml}$ neomycin sulfate, to obtain CEP [9]. Carbohydrate concentration of the elicitor preparations were determined as D-glucose equivalents, using the phenol-sulfuric acid technique [11].

\subsection{Fractionation of CEP on a Sephacryl S-300 column}

CEP (500 $\mu \mathrm{l}$ containing $500 \mu \mathrm{g}$ glucose equivalent) was applied to a $2.5 \times 28 \mathrm{~cm}$ column of Sephacryl S-300 (Pharmacia) equilibrated and eluted with MES $0.03 \mathrm{M}(\mathrm{pH} \mathrm{6.2)}$ at $1 \mathrm{ml} / \mathrm{min}$. Fractions $(0.5-\mathrm{ml})$ were collected to make the EP. Carbohydrate concentration and scoparoneeliciting activity were determined as shown below. 


\subsection{Assay of elicitor preparations}

Leaves taken from rough lemon plants grown in a greenhouse, were surface-sterilized for $5 \mathrm{~min}$ in $2 \% \mathrm{NaClO}$, followed by 2 washes with distilled water. They were then placed, adaxial side up, on moist filter papers. A longitudinal incision (5-mmlong) was made with a scalpel along the main vein of each leaf, followed by lifting up veinal tissue and some adjacent epidermis. Twenty $\mu$ l of CEP or $\mathrm{EP}$ (containing $20 \mu \mathrm{g}$ glucose equivalent in MES buffer) were deposited into each leaf incision; control leaves were treated similarly with MES buffer. To test the biological effects of CEP or EP on infection, leaves were then placed to float on 0.03 M MES ( $\mathrm{pH} \mathrm{6.2)} \mathrm{for} 2 \mathrm{~h}$, before inoculating them as described above. The diameter of lesions was recorded after 5 days in the dark.

In order to evaluate scoparone induction by CEP or EP, non-inoculated control leaves were incubated for 4 days in the dark at $25^{\circ} \mathrm{C}$. A leaf disk, $2 \mathrm{~cm}$ in diameter, containing the wounded site and the elicitor droplet, was then excised from each site. Scoparone concentrations were determined by the method of Afek and Sztejnberg [12] and Sulistyowati et al. [13], using $1 \mathrm{~g}$ fresh weight of tissue collected from several treated leaves.

\section{Results}

Results showed scoparone accumulation (71 $\mu \mathrm{g} / \mathrm{g}$ fresh weight) and protection against infection (lesions of $9 \mathrm{~mm}$ ), in Citrus leaves floating on 10 $\mu \mathrm{g} / \mathrm{ml} \mathrm{H}_{3} \mathrm{PO}_{3}$ and inoculated with the $\mathrm{S}$ strain, but not in leaves inoculated with the RI mutant (Table 1).

Pretreatment with AOA had no effect on lesion size and scoparone accumulation in leaves floating on MES. However, such pretreatment sharply decreased scoparone concentration $(12.6 \mu \mathrm{g} / \mathrm{g}$ vs. $71 \mu \mathrm{g} / \mathrm{g})$ and increased lesion size $(25 \mathrm{~mm}$ vs. 9 $\mathrm{mm})$, in leaves floating on $\mathrm{H}_{3} \mathrm{PO}_{3}(10 \mu \mathrm{g} / \mathrm{ml})$ and inoculated with the $\mathrm{S}$ strain, while showing no effect on scoparone concentration or lesion size in leaves inoculated with the RI strain.

Eliciting activity of CEP (adjusted at $20 \mu \mathrm{g}$ glucose equivalent in $20 \mu$ l) was estimated by quantifying scoparone accumulation in $1-\mathrm{g}$ aliquots of leaf tissue. The protective effect of CEP treatment towards subsequent infection by $P$. citrophthora, was evaluated by measuring the diameter of lesions (Table 2).

Scoparone accumulation was observed in leaves treated with CEP released upon mycelia incuba-

Table 1

Diameter of lesions and concentration of scoparone in Citrus leaves floating on different solutions and inoculated with $P$. citrophthora strains

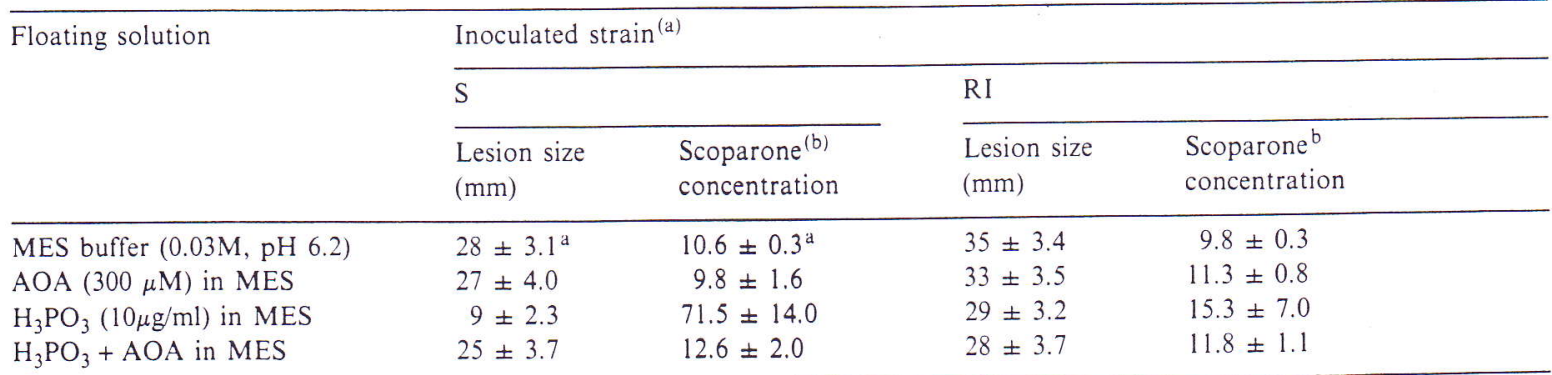

${ }^{a} \mathrm{~S}, \mathrm{H}_{3} \mathrm{PO}_{3}$ sensitive strain; $\mathrm{RI}, \mathrm{H}_{3} \mathrm{PO}_{3}$ relatively insensitive strain. Data are the mean result of 4 independent experiments with 10 replicates \pm S.D.

${ }^{b}$ Scoparone concentrations are expressed as $\mu \mathrm{g} / \mathrm{g}$ fresh weight of leaf tissue. Application of MES buffer onto the wound (noninoculated control) produced $0.1 \mu \mathrm{g} / \mathrm{g}$ of scoparone. 


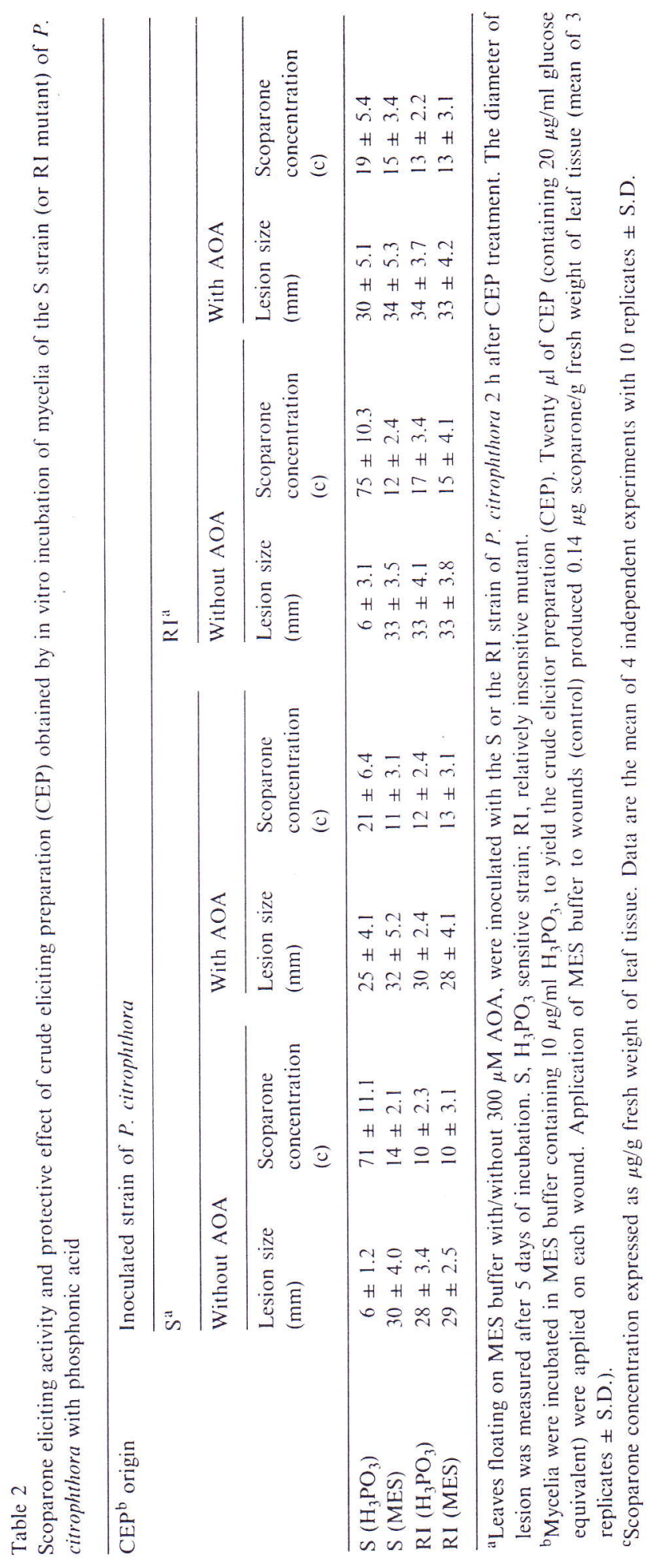


Table 3

Scoparone eliciting activity of different preparations made from CEP of mycelia from the S strain of Phytophthora citrophthora incubated or non-incubated in phosphonic acid

\begin{tabular}{|c|c|c|c|c|}
\hline \multirow{2}{*}{$\begin{array}{l}\text { Eliciting } \\
\text { preparation }^{\mathrm{a}}\end{array}$} & \multicolumn{2}{|c|}{ Mycelia incubated in MES buffer } & \multicolumn{2}{|c|}{ Mycelia incubated in $10 \mu \mathrm{g} / \mathrm{ml} \mathrm{H}_{3} \mathrm{PO}_{3}$} \\
\hline & $\%$ glucose & $\begin{array}{l}\text { Scoparone } \\
\text { concentration }\end{array}$ & $\%$ glucose & $\begin{array}{l}\text { Scoparone } \\
\text { concentration }\end{array}$ \\
\hline CEP & 100 & $10 \pm 0.4^{b}$ & 100 & $74 \pm 11.3$ \\
\hline A & 12 & $7 \pm 2.4$ & 26 & $46 \pm 4.2$ \\
\hline B & 29 & $12 \pm 3.2$ & 21 & $14 \pm 3.8$ \\
\hline $\mathrm{C}$ & 14 & $7 \pm 3.0$ & 32 & $12 \pm 4.6$ \\
\hline D & 16 & $9 \pm 2.5$ & 18 & $8 \pm 3.4$ \\
\hline
\end{tabular}

${ }^{a} \mathrm{CEP}$ was obtained by incubating the mycelia of $\mathrm{S}$ strain in $\mathrm{H}_{3} \mathrm{PO}_{3}$ and was then submitted to chromatography on Sephacryl S-300 column. Eighty fractions were collected and pooled to make 4 eliciting preparations (A,B,C,D) which were applied at the rate of $20 \mu \mathrm{g}$ glucose equivalent on each wounded site of Citrus leaves. Scoparone concentration are expressed as $\mu \mathrm{g} / \mathrm{g}$ fresh weight of leaf tissue.

${ }^{b}$ Mean of 3 replicates \pm S.D.

tion of the $\mathrm{S}$ strain of $P$. citrophthora in $\mathrm{H}_{3} \mathrm{PO}_{3}$ (but not with a similar preparation with the mycelia of RI mutant). Correlatively, the size of lesions induced by inoculating either S or RI strain was sharply reduced by treatment of leaves with CEP of the $\mathrm{S}$ strain (but not with a similar preparation of the RI mutant).

Pretreatment with AOA of leaves submitted to application of CEP of the $\mathrm{S}$ strain, reduced scoparone accumulation to the levels found in leaves without CEP, and increased correlatively the size of the lesions formed after inoculation of either $\mathrm{S}$ or RI strains.

CEP was fractionated into 80 fractions by column chromatography on Sephacryl S-300. A first peak (fractions 30-40) was present only in the preparation from $\mathrm{S}$ strain incubated in $\mathrm{H}_{3} \mathrm{PO}_{3}$. A second peak (fractions 40-60) was observed in all 4 combinations ( $\mathrm{S}$ or RI strain incubated in either $\mathrm{H}_{3} \mathrm{PO}_{3}$ or MES buffer). Fractions 30-40 were pooled to make preparation $\mathrm{A}$, while fractions 40-60 were used to make preparations $\mathrm{B}, \mathrm{C}$ and $\mathrm{D}$, which were tested for their scoparone eliciting activity and their protective effect (Table 3 ). Scoparone accumulation was found only in leaves treated with CEP of S strain incubated in $\mathrm{H}_{3} \mathrm{PO}_{3}$ (but not with CEP of S strain incubated in MES). After chromatography on Sephacryl column, scoparone eliciting activity was mainly located in preparation A, which contained $26 \%$ of CEP glucose equivalent (Table 3). Application of frac- tion A (20 $\mu \mathrm{g}$ glucose equivalent) to Citrus leaves induced the accumulation of $46.5 \mu \mathrm{g}$ scoparone $/ \mathrm{g}$ fresh weight of leaf tissue (as compared to 8.3$14.2 \mu \mathrm{g}$ scoparone/g with fractions B, C or D).

Table 4

Effect of treatment of Citrus leaves with different scoparone eliciting preparations, on subsequent infection by $P$. citrophthora

\begin{tabular}{llcc}
\hline $\begin{array}{l}\text { Inoculated } \\
\text { strain }^{\text {a }}\end{array}$ & $\begin{array}{l}\text { Eliciting } \\
\text { preparations }\end{array}$ & \multicolumn{2}{c}{ Size of lesions $(\mathrm{mm})$} \\
\cline { 3 - 4 } & & $\mathrm{MES}-\mathrm{CEP}^{\mathrm{c}}$ & $\mathrm{H}_{3} \mathrm{PO}_{3}$-CEPc \\
\hline $\mathrm{S}$ & $\mathrm{CEP}$ & $29 \pm 3.1$ & $6 \pm 1.1$ \\
& $\mathrm{~A}$ & $30 \pm 4.0$ & $7 \pm 1.4$ \\
& $\mathrm{~B}$ & $29 \pm 2.3$ & $27 \pm 2.5$ \\
& $\mathrm{C}$ & $29 \pm 2.1$ & $26 \pm 3.7$ \\
& $\mathrm{D}$ & $28 \pm 3.2$ & $28 \pm 3.2$ \\
& & & \\
$\mathrm{RI}$ & $\mathrm{CEP}$ & $33 \pm 2.4$ & $5 \pm 1.5$ \\
& $\mathrm{~A}$ & $32 \pm 2.7$ & $6 \pm 1.7$ \\
& $\mathrm{~B}$ & $34 \pm 3.4$ & $34 \pm 2.2$ \\
& $\mathrm{C}$ & $33 \pm 3.5$ & $33 \pm 3.4$ \\
& $\mathrm{D}$ & $34 \pm 2.8$ & $30 \pm 4.2$ \\
\hline
\end{tabular}

anoculation with the $\mathrm{H}_{3} \mathrm{PO}_{3}$-sensitive $\mathrm{S}$ strain, or with the $\mathrm{RI}$ relatively insensitive mutant, were performed $2 \mathrm{~h}$ after treatment of Citrus leaves with the total crude eliciting preparation (CEP), or with the different eliciting preparations $(30 \mu \mathrm{g} g) \mathrm{u}-$ cose equivalent).

${ }^{b} A, B, C, D$, : eliciting preparations obtained after chromatography of CEP on Sephacryl S-300 column.

${ }^{c} \mathrm{CEP}$ obtained by incubating mycelia of $\mathrm{S}$ strain of $P$. citrophthora in MES pH 6.2 amended with/without $10 \mu \mathrm{g} / \mathrm{ml}$ $\mathrm{H}_{3} \mathrm{PO}_{3}$. 
Correlatively, treatment of wounds with CEP released by $\mathrm{S}$ mycelia incubated in $\mathrm{H}_{3} \mathrm{PO}_{3}$ (or with preparation A obtained after CEP chromatography on Sephacryl), greatly reduced the diameter of lesions formed by inoculating the $\mathrm{S}$ strain or the RI mutant of $P$. citrophthora, while preparations $\mathrm{B}, \mathrm{C}$ or $\mathrm{D}$ had no effect on lesion size for both strains (Table 4).

\section{Discussion}

Afek and Sztejnberg [8] reported that the phytoalexin scoparone accumulated in Citrus stems inoculated with $P$. citrophthora in the presence of fosetyl-Al. Scoparone accumulation was also observed in inoculated genetically resistant varieties [4]. Besides, Saindrenan et al. [14] showed that in vitro treatment of the mycelia of Phytophthora cryptogea with $\mathrm{H}_{3} \mathrm{PO}_{3}$ released compounds eliciting a resistance response towards this fungus in Vigna unguiculata.

We found that inoculation with $P$. citrophthora of detached Citrus leaves floating on $10 \mu \mathrm{g} / \mathrm{ml}$ $\mathrm{H}_{3} \mathrm{PO}_{3}$ provides a suitable experimental model to test the relationship between scoparone accumulation and induction of resistance to this fungus. In all our experiments, incompatible reactions in planta were associated with scoparone accumulation, as shown in $\mathrm{H}_{3} \mathrm{PO}_{3}$-treated leaves inoculated with the $\mathrm{S}$ strain, and in CEP-treated leaves inoculated with either the S or the RI strain. Correlatively, the compatible reaction observed in planta by inoculating $\mathrm{H}_{3} \mathrm{PO}_{3}$-treated leaves with the RI strain was linked to low scoparone content. Periodate oxidation of CEP gradually decreased its scoparone eliciting capacity, together with the protection effect it induced, thus suggesting that scoparone accumulation and leaf protection are related to the release of carbohydrate elicitors [15].

The cross protection phenomenon, by virtue of which Citrus leaves preinoculated with the S strain of $P$. citrophthora in the presence of $\mathrm{H}_{3} \mathrm{PO}_{3}$ were protected against superinfection by the RI strain [7], was also linked to scoparone accumulation (unpublished results). All incompatible reactions became compatible when $\mathrm{H}_{3} \mathrm{PO}_{3}$-treated leaves were pretreated with $\mathrm{AOA}$ thus suggesting a role of the phenylpropanoid pathway in inducing the defence mechanism correlated to scoparone accumulation. Our overall results indicate that application to Citrus leaves of scoparone elicitors released by in vitro incubation of the mycelia of the $\mathrm{S}$ strain of $P$. citrophthora in $10 \mu \mathrm{g} / \mathrm{ml} \mathrm{H}_{3} \mathrm{PO}_{3}$, mimic all in planta results obtained upon inoculation by the $\mathrm{S}$ or the RI strain, respectively, both in terms of compatible (or incompatible) reactions and in terms of scoparone accumulation.

\section{References}

I Y. Cohen and M.D. Coffey, Systemic fungicides and the control of oomycetes. Ann. Rev. Phytopathol., 24 (1986) $311-338$.

2 G. Bompeix, A. Ravise, G. Raynal, F. Fettouche and M.C. Durand, Modalités de transmission de l'obtention des nécroses bloquantes sur feuilles détachées de tomate par l'action du tris- $O$-éthyl phosphonate d'aluminium (phoséthyl d'aluminium), hypothèses sur son mode d'action in vitro. Ann. Phytopathol., 12 (1980) 337-351.

3 D.I. Guest, Modification of defence responses in tobacco and capsicum following treatment with fosetyl-Al (aluminium tris (o-ethyl phosphonate). Physiol. Plant Pathol., 25 (1984) 125-134

4 A.J. Khan, A. Vernenghi and A. Ravise, Incidence of fosetyl-AL and elicitors on the defence reactions of Citrus attacked by Phytophthora sp. Fruits, 41 (1986) 587-595.

5 T.E. Dolan and M.D. Coffey, Correlative in vitro and in vivo behavior of mutant strains of Phytophthora palmivora expressing different resistances to phosphorous acid and fosetyl-Na. Phytopathology, 78 (1988) 974-978.

6 M.E. Fenn and M.D. Coffey, Further evidence for the direct mode of action of fosethyl-Al and phosphorous acid. Phytopathology, 75 (1985) 1064-1068.

7 M.K. Ali, Prémunition contre l'infection de feuilles de Citrus limon par des souches de Phytophthora citrophthora en présence de tris-o-éthyl phosphonate d'aluminium. Bull. Rech. Agron. Gembloux, 24 (1989) 329-334.

8 U. Afek and A. Sztejnberg, Effects of fosetyl-Al and phosphorous acid on scoparone, a phytoalexin associated with resistance of Citrus to Phytophthora citrophthora. Phytopathology, 79 (1989) 736-739.

9 M.K. Ali, P. Lepoivre and J. Semal, Fosetyl-Al treatment of mycelium of $P$. citrophthora releases a higher scoparone elicitor activity from a fosetyl-Al sensitive strain than from an insensitive mutant. Fruit, 46 (1991) 51-55.

10 M.K. Ali, P. Lepoivre and J. Semal, In vitro selection of Phytophthora citrophthora isolates resistant to phosphorous acid and fosetyl-Al. Med. Fac. Landbouww. Rijksuniv. Gent., 53/2b (1988) 597-604.

11 M. Dubois, K.E. Gilles, J.K. Hamilton, P.A. Rebers and F. Smith, Colorimetric method of determination of sugar and related substances. Anal. Chem., 28 (1956) 350-356.

12 U. Afek and A. Sztejnberg, Accumulation of scoparone, 
a phytoalexin associated with resistance of citrus to Phytophthora citrophthora. Phytopathology, 78 (1988) $1678-1682$.

13 L. Sulistyowati, P.J. Keane and J.W. Anderson, Accumulation of the phytoalexin 6,7-dimethoxycoumarin, in roots and stems of Citrus seedlings following inoculation with P. citrophthora. Physiol. Mol. PIant Pathol., 37 (1990) 451-461.

14 P. Saindrenan, T. Barchietto and G. Bompeix, Effects of phosphonate on the elicitor activity of culture filtrates of
Phytophthora cryptogea in Vigna unguiculata. Plant Sci., 67 (1990) 245-251.

15 M.K. Ali, P. Lepoivre and J. Semal, Scoparone elicitors released upon fosetyl treatment of Phytophthora citrophthora mycelium protect Citrus leaves against subsequent infection by this fungus. Proceeding of the 2 nd conference of EFPP 'Mechanisms of Plant Defense Response'. Strasbourg, August 1992. Kluwer Academic Publisher, 1993, p. 173 (Abstract). 